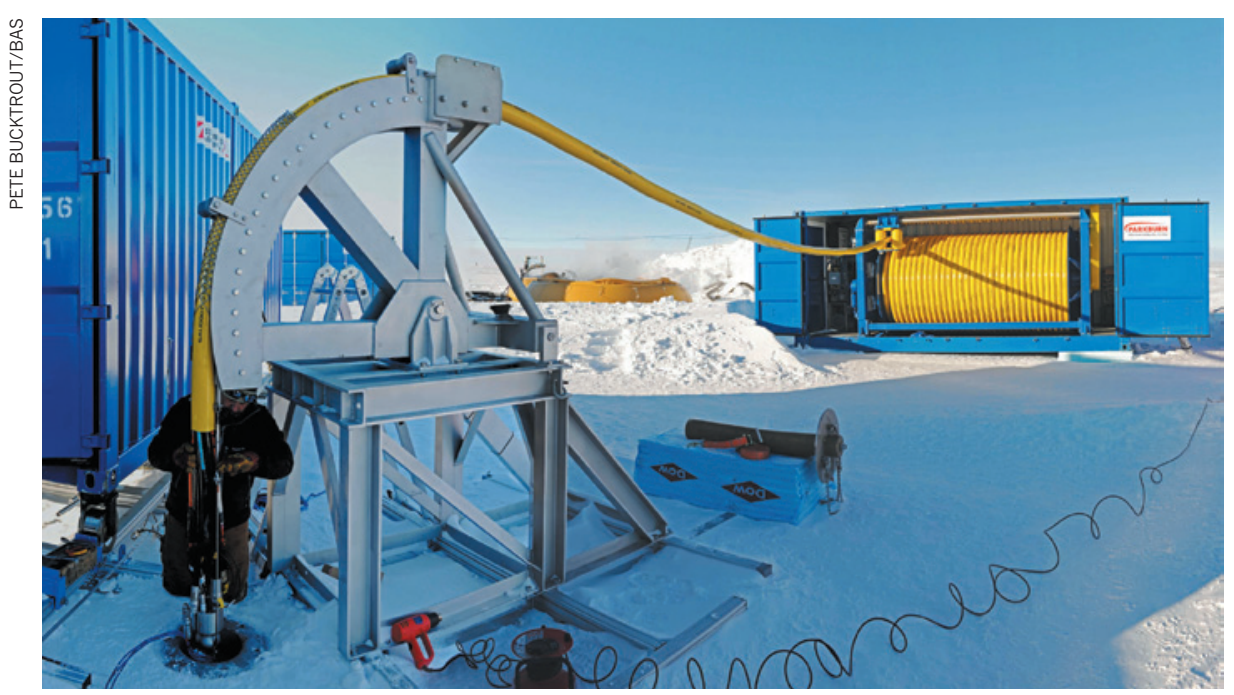

A 2012 attempt to drill through a 3-kilometre-thick Antarctic ice sheet faced technical difficulties.

\title{
ANTARCTIC RESEARCH
}

\section{Polar drilling}

problems revealed

\section{Report into failings of expedition to explore Antarctic lake finds equipment to blame - but complications can be fixed.}

\section{BY QUIRIN SCHIERMEIER}

C hristmas Day 2012 was a very bad day for glaciologist Martin Siegert and his team of Antarctic researchers. After weeks of equipment failures, Siegert was forced to halt an ambitious attempt to drill into a lake deep beneath the West Antarctic Ice Sheet. "The decision was difficult to make but easy enough to call," he noted in his field diary. Exhausted and disappointed, the team packed up.

But it has not given up. Over the past year, researchers, engineers and officials involved in the US\$12-million drilling project, funded by the UK Natural Environment Research Council, have carried out and responded to several internal reviews into the reasons for its failure. And now, in a paper under review by the Annals of Glaciology, Siegert, who is based at the University of Bristol, UK, and his colleagues have summarized the problems that they suffered at Lake Ellsworth and laid out options for putting them right. They think that several years of engineering work will be required to develop improved technology for a more reliable drill, but they say that success is achievable.

"I am glad to see that they plan to publish their drilling efforts," says John Priscu, a glaciologist at Montana State University in Bozeman who has worked on similar lake-drilling projects in western Antarctica. "It will quell rumours and provide a solid bit of groundwork on which they can move forward."

Lake Ellsworth is one of several hundred lakes beneath Antarctica's ice sheets (see 'Hidden lakes'). Scientists suspect that the extended basins, isolated for possibly millions of years, support specially adapted forms of life. Organisms that may thrive in the extreme environment could even bear clues as to the biology of extraterrestrial life, such as any that might exist in a suspected ocean beneath the icy surface of Europa, one of Jupiter's moons.

The Ellsworth project was in planning for

\section{HIDDEN LAKES}

Antarctica has about 400 subglacial lakes, some of which have been isolated for millions of years.

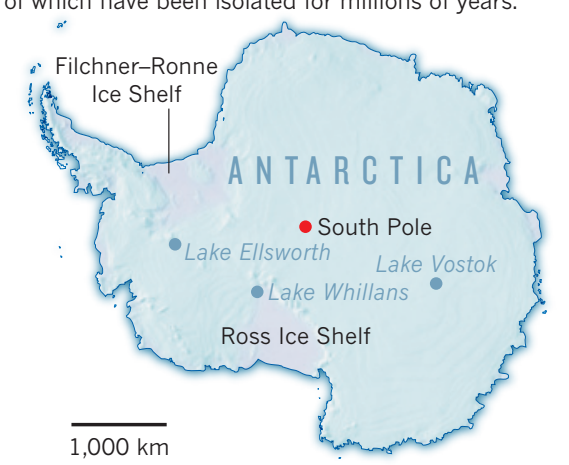

more than ten years. The teardrop-shaped lake, about 15 kilometres long and up to 156 metres deep, and in a valley, was extensively charted with seismic methods and ice-penetrating radar by the team before the drilling attempt.

After arriving at the lake in early December 2012, Siegert's team had hoped to cut through the 3-kilometre-thick ice sheet in a single 72-hour effort. A specially developed hotwater drilling technique, devised by engineers at the British Antarctic Survey, was designed to minimize air and water pollution.

According to the paper, problems started when the boiler that was intended to melt large quantities of snow to provide hot water for the drill failed to work properly because of shortcircuiting in its control panel. More severe problems followed. The two parallel drills - one to drill the main borehole to reach the lake, and one to create a reservoir cavity to recirculate drilling water - ran too slowly. Other failures, including of components designed to ensure vertical drilling, exacerbated the problems.

"The drilling was essentially undertaken blindly," says Siegert. Probably because one or both holes were not drilled vertically, the cavity failed to link with the main borehole. Water also leaked into the cavity drill and froze the hose in the drill hole. Attempts to remove the hose failed, so it had to be cut. At that point, and with not enough fuel left to reach the lake, Siegert gave up.

His report into the project suggests a number of steps to improve the drilling system: sensors need to be thoroughly tested for reliability under conditions comparable to Antarctica's harsh environment, spare parts must be available on the site, and a field team must include electrical engineers to assist with on-site operations.

The method is not fundamentally flawed, however. Last year, Priscu and his team successfully used a hot-water drill to explore Lake Whillans, a small body of water on the edge of the Ross Ice Shelf in western Antarctica. The lake, which is not as deep as Ellsworth, does seem to harbour microbial life (see Nature http://doi.org/q3m; 2013).

There are other reasons for pursuing hotwater drill technology. In 2012, Russian scientists broke into Lake Vostok, by far the largest of Antarctica's hidden lakes, using a kerosenefuelled drill. But their samples are spoiled with drill fluid and the bacteria they contain are probably contaminant species.

Consideration of what went wrong at Ellsworth should result in a revised plan for a return mission, says Mahlon Kennicutt, chair of the Lake Ellsworth advisory committee. The team hopes to formally propose a second attempt in five years.

"Antarctic science is by its nature risky," says Kennicutt. "However, the potential gains in knowledge outweigh the costs and the risks in most cases, and this is especially true for the exploration of subglacial aquatic environments." - 